Submitted $17^{\text {th }}$ August 2021

Accepted $28^{\text {th }}$ October 2021

\title{
ONLINE TO OFFLINE SALES METHOD IN THE E- COMMERCE INDUSTRY IN DENPASAR
}

\author{
Nyoman Sri Subawa1, I Wayan Agus Budiadnyana ${ }^{2}$ \\ Master of Management Study Program, National Education University, Bali, Indonesia \\ gusbudi58@gmail.com
}

\begin{abstract}
The purpose of this study is to determine the use of the online to offline (O2O) sales method in the e-commerce industry in Denpasar and to know the application of online to offline (O2O) can increase trust in e-commerce. The research design used in this study is a qualitative approach. The data collection techniques used were observation, interview, and documentation. The results of this study indicate the use of the online to offline sales method has many benefits if it is supported by adequate facilities and infrastructure, besides that the selection of offline stores must also be strategic. to facilitate customers to take goods that have been ordered online, in this study it was found that the sales method online to offline can answer any doubts of consumers and change the social status of e-commerce. Using online to offline service dimensions in the form of physical evidence, reliability, responsiveness, assurance, and empathy can increase consumer confidence in ecommerce.
\end{abstract}

Keywords: Service Online to Offline, Consumer Confidence, E-Commerce

\section{INTRODUCTION}

E-commerce is a form of electronic commerce via the internet. $E$ commerce is basically a contact trade transaction between sellers and buyers using the internet media. Shopping in the industry of e-commerce becomes a habit for s ost people because of the convenience provided, many people think that shopping online is one of the means to look for items that are needed, because $e$ commerce provides much convenience for both parties, either of the parties sellers and buyers in conducting trade transactions (Harahap, DA \& Amanah, D. 2018 ). This is in line with research conducted by Setyawan et al (2017) who show that sales results using e-commerce are more effective than sales results without using the e-commerce method. Media social, Facebook has become the most effective social media use compared to other social media. So it's no wonder that this increase will boost the value of Indonesia's e-commerce market.

Although consumers have many advantages of using e-commerce, $e$ commerce users also have obstacles. The obstacle that is often faced is the low level 
of trust among the community. Still, many buyers who do not believe will be the goods bought. Sometimes items purchased online are not what the buyer expected. In addition, it is difficult for the community to change their habit of making transactions without meeting directly with the seller (Anggiani. 2018). This is also in line with research by Aco and Endang (2017) which states that most people feel hesitant about making payments by credit card because of the many cases of fraud. This certainly lowers public confidence in e-commerce. In addition, there are also a small number of people who do not believe in the e-commerce business. People tend to come directly to the store to buy the goods they want. Consumer trust in online products is needed in running an e-commerce business. Trust is basically a form of consumer support for products or services offered by e-commerce players related to purchasing decisions. This can be said that with an increase in trust in e-commerce, it can also increase online product sales (Sugara \& Dewantara, 2017). The method of selling online to offline can use e-commerce to get the trust of consumers. Service online to offline ( 020 ) is a way new to make the sales process e-commerce. The concept of online to offline services basically makes it easy for consumers to transact online. Implementation of online to offline will give comfort for consumers to shop for items that will be accepted by consumers can take to ordinary consumers who already work with e commerce. Thus, consumers can see the goods directly before buying the goods. In addition, online to offline can reduce shipping costs which can be said to be quite high if the area coverage is too far. Wardhanie, AP et al (2018) said that the online to offline business model not only changes the mentality of consumers but this service model also brings its own challenges to the e-commerce industry, it can be said that the current e-commerce model is looking for new ways to combine online with offline.

Denpasar is the largest city in the Nusa Tenggara Islands and is the city center in the province of Bali. The industrial growth on the island of Bali has pushed the city of Denpasar to become the center of business activities. This is what causes the number of e-commerce to develop in Denpasar City. One of the $e$ commerce services is online to offline $(\mathrm{O} 2 \mathrm{O})$. although the use of online to offline $(\mathrm{O} 2 \mathrm{O})$ services in Denpasar is still limited, online to offline services have great potential to be developed.

Based on the description of the background of the problem while the problem in this research are: how to use methods of selling online to offline (o2o) in the industry of e-commerce in Denpasar? and Can the application of online to offline $(\mathrm{O} 2 \mathrm{O})$ increase trust in e-commerce in Denpasar ?. Following the formulation of the research problem, the objectives of this study are: knowing the use of the online to offline (O2O) sales method in the e-commerce industry in Denpasar and knowing the application of online to offline $(\mathrm{O} 2 \mathrm{O})$ can increase trust in e-commerce in Denpasar. The benefits of the theoretical in the research are: (1) provide knowledge and understanding of the use of methods of selling online to offline (o2o) in the industry of e-commerce in New York City and became a reference for further research. (2) The results of this study are expected to be used as a basis for preliminary information and data as well as a basis for further researchers who are interested in researching matters relating to 
the e-commerce industry. While the benefits of the practice in this study are: (1) for business practitioners of e-commerce, hacyl research is expected to be considered for industrialists e-commerce in Denpasar to use the method of selling online to offline ( 020$)$ as a method in sales of its products. (2) for consumers the use of services online to offline (o2o) consumers will feel more comfortable shopping online because consumers can take Brang purchased online in physical store e-commerce such.

E-commerce can be defined as an arena for transactions or exchanges of information between sellers and buyers who take advantage of today's developing internet technology. E-commerce exists because of the demands of the lifestyle of modern society that demands convenience and speed in all fields (Rerung, 2018. Page 18). Sarwono and Prihartono (2012) revealed that e-commerce $i s$ related to buying and selling transactions carried out digitally. Another opinion defines e-commerce as a series of trading business activities that partly or entirely uses the internet as a means of communication (Sakti. 2014). So, based on some of the explanations above, it can be concluded that e-commerce is a means of online trading that involves sellers and buyers using the internet as a means of communication. This is done because of the demands of the community who want convenience and what they want is quickly obtained.

To get the success of using e-commerce, business people must be able to find ways to get customer satisfaction, loyalty, and good relationships with consumers online. The keys to the success of e-commerce players, namely (Anggiani, S. 2018: page 223 ): (1) Options and values. Choice and value factors include attractive product choices, competitive prices, satisfaction guarantees and customer support after the sale. These things are very necessary for e-commerce players in selling their products. (2) Performance and service. Performance and service factors include navigation, shopping and purchasing processes as well as fast and easy delivery confirmation. (3) Look and Feel. Appearance and taste factors include web displays, websites, shopping areas, multimedia products, catalog pages and exciting shopping features. (4) Advertising and incentives. Advertising factors and incentives include web, targeted $e$ mail promotions and special offers, including advertisements on various affiliate sites. (5) Personal attention. Personal attention factors include personalized web pages, personalized product suggestions, web advertising and e-mail notifications, and interactive support for all consumers. (6) Relations with the community. The relationship factor with the community includes the virtual community of consumers, suppliers, business representatives, and others through news groups, chat rooms, and various links to related sites. (7) Safety and reliability. Security and reliability factors include the security of consumer communications and website transactions, reliable product information, and executable order fulfillment.

Trust is a person's belief in other people in making transactions. Business transactions will occur if there is mutual trust between consumers and sellers. Trust is the initial capital in starting a business and will be a driving force in an effective relationship (Subagio \& Veno, M. 2013). Meanwhile, Soegoto, S. A (2013) states that trust that is built from scratch will foster a sense of consumer loyalty to the goods or services offered. Consumer trust is a consumer's hope that a provider of 
goods or services can be relied on in fulfilling their promises (Bilondatu, MR 2013). So, trust in consumers is an absolute requirement that e-commerce players must do so that the business they build can develop because trust can foster a sense of consumer loyalty so that consumers will buy products or use services offered in a sustainable manner.

According to Luarn and Lin (in Ferrinadewi, 2008: page 147), the components of trust include: (1) Integrity. Integrity is the ability to keep promises that have been agreed upon from trusted parties (sellers). Integrity relates to how the seller's behavior or habits in conducting his business. Integrity can be seen from the point of view of reasonableness, fulfillment, loyalty, straightforwardness, linkage, and reliability. (2) Kindness (Benevolence). The goodness of the day is a concern and motivation to act in accordance with the interests of consumers by product providers. Kindness is the seller's willingness to provide mutually beneficial satisfaction between the seller and the consumer. Kindness includes attention, empathy, confidence, and acceptance. (3) Competency. Competency is the seller's ability to carry out the needs of consumers. In this case, the seller is how the seller is able to provide, serve, to secure transactions from interference from other parties. This means that consumers get security guarantees during the transaction process. Competency includes experience, institutional endorsement and ability in science. (4) Predictability. Predictability is the consistency of the seller. The salesperson's ability to provide certainty about the goods being sold, so that consumers can anticipate it. Predictability includes self-image of the seller, predictable risk and consistency.

Services offline is a service that does not need to use the internet as a means of communication. Consumers only need to come to a physical shop to buy the desired item. The growing digital world does not rule out the possibility of people still using offline services or offline shop consumers ( Masruri \& Creativity. 2012 ).

According to Faizah, NK (2018) as for the advantages and disadvantages of offline services, among others: the advantages of offline services, namely sellers and buyers can interact directly so that they can build a close relationship between the two. Consumers get easy trust because of real shops and products. Consumers can choose their own desired model, try the appropriate size and find out the quality of the materials used. While the disadvantage of offline services is the limitation in marketing using offline services is that the marketing target is not broad which is constrained by regional boundaries. Because offline services are a real area, a place is needed to accommodate all the products being marketed.

Online to offline is a business strategy that attracts consumers from the online world to physical stores or the offline world. The online to offline service uses the brick and click company e-commerce concept. The online to offline strategy is carried out by the company to invite consumers to the online world, by means of promotion via e-mail, advertisements via the internet and others to visit physical stores so they can pick up items that have been purchased or conduct surveys like what items are purchased and make purchases online. online (Amban, HE 2016: p. 11). Meanwhile, Kotler, P. (2017: p. 87) adds that online to offline is the basic principle for connecting the online digital world with the offline world through the integration of devices connected to the internet. Consumers who start shopping online are then encouraged to get services 
at offline stores. So it can be concluded from the two definitions that online to offline is a combination of trading via online and offline, where consumers transact online and then take goods that have been purchased by consumers at the seller's physical shop.

Suryani (2013: p. 91) suggests the service dimensions used to evaluate the use of online to offline services: (1) Physical Evidence (Tangibes). This is shown by the company's ability to show its existence to external parties. Du, Y and Tang, Y (2014) added that when consumers search for online services and enter physical stores, consumers see a gap between expectations and actual shop facilities, consumer satisfaction will decrease and online to offline services will be doubted. Therefore online to offline services urge physical stores to provide accurate information on the internet so that consumers can browse it. The more detailed information on the internet about the physical store stronger, the trust of consumers. (2) Reliability. The company's ability to provide the promised services accurately and reliably. Du, Y and Tang, Y (2014) added that if consumers think that they don't get all the services they buy online, consumers will doubt the correctness of the information online. Reliability also includes whether the physical store has the qualifications to provide the online to offline service. Responsiveness. A willingness to help and provide services quickly and precisely to customers through the delivery of clear information. Service staff plays an important role during the service process. Whether the staff can provide good service because it will directly affect customer satisfaction. (4) Assurance. Knowledge, politeness and ability of company employees to foster customer trust in the company. Consumers make transactions online and expect to get professional service by employees at physical stores. This will result in high demand for quality service staff. (5) Empathy. The ability of the company or company staff to give genuine personal attention to customers and understand the needs of customers. Du, Y and Tang, Y (2014) added that empathy emphasized that physical stores care about customers and give some other special attention. If consumers experience pleasant service, they will make consumers feel happier to transact online.

Based on the theoretical and empirical studies that have been described previously, the researcher created a frame of mind which can be seen in Figure 1. below. 


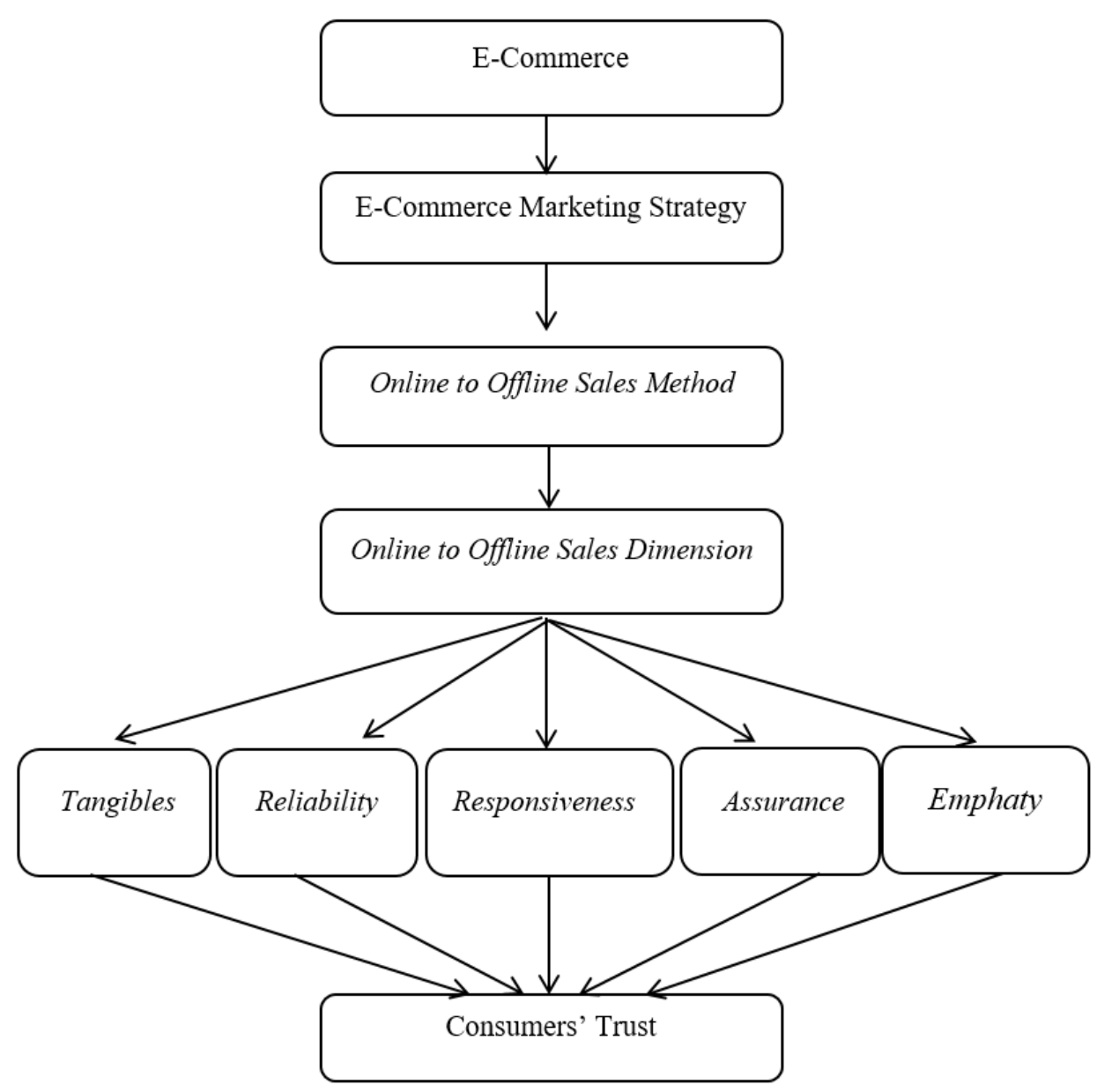

Figure 1

Conceptual framework

Online to Offline Services Research in the E-Commerce Industry in Denpasar

\section{METHODOLOGY}

The research approach used in this research is descriptive qualitative. Qualitative methods are used in research with object conditions that are natural, not experimental. Qualitative research generally better understands the experiences, attitudes, and opinions of an individual or a group of people. In his study, researchers took the case of the development of online to offline $(\mathrm{O} 2 \mathrm{O})$ services in the E-Commerce industry in Denpasar. In the process, the researchers studied the development of services online to offline from the use of these services by observation, interview and documentation study.

This research will be conducted in the E-Commerce Industry in Denpasar. E-commerce was chosen because in the present era e-commerce is very developed and has become a sales method that is widely used by business people. In addition, researchers chose Denpasar because Denpasar is the largest city in the 
Nusa Tenggara Islands and is the city center in the province of Bali. The industrial growth on the island of Bali has pushed the city of Denpasar to become the center of business activities. This is what causes the number of e-commerce to develop in Denpasar City.

The data collection techniques used were observation, interviewing, and documentation. Observation is the observation of an object under study to obtain data that must be collected in the research. In the context of qualitative research, observation is not to test the truth but to find out the truth related to an aspect or category as an aspect of the study developed by the researcher. (Satori, D \& Komariah, A. 2017: p. 106). In this study, the researcher wanted to know the use of online to offline services for e-commerce directly. Interviews are used to obtain information obtained from direct data sources through conversations and questions and answers. The main purpose of conducting interviews is to be able to present current constructs in a context regarding persons, events, activities, organizations, feelings, motivations, responses or perceptions, levels, and forms of involvement, etc., to reconstruct such things as part of the experience. past, and projecting those things that are associated with hopes that can happen in the future (Sutopo, 2006). In this study, researchers conducted interviews with $e$ commerce industry players in Denpasar and consumers of e-commerce. Interviews were conducted in-depth. Documentation study in qualitative research is a complement to the use of observation and interview methods. The results of observations and interviews will be more credible or trustworthy if they are supported by documents related to the research focus (Satori, D \& Komariah, A. 2017: p. 149).

The research subjects used were informants who knew all the information needed by the researcher during the research process. Suyanto (2005) states that in qualitative research, research informants include three types, namely: (1) Key informants, namely informants who know and have comprehensive information about the problems raised by the researcher. in this case, the e-commerce players are the key informants. (2) The main informants are informants who are directly involved in the social interactions studied. In this study, additional informants are consumers who shop throughe-commerce. (3) Additional informants are informants who can provide information even though they are not directly involved in the social interactions studied. In this study, researchers did not use additional informants. The following is the description of the informants to be studied:

Table 1. Research informants

\begin{tabular}{clc}
\hline No. & \multicolumn{1}{c}{ Informant } & total \\
\hline 1 & E-Commerce Players & 3 \\
\hline 2 & Consumer $E$-Commerce & 2 \\
\hline
\end{tabular}

After the data is collected, the next step is data analysis. The purpose of data analysis is to simplify the data into a form that is easier to read and interpret. In this study, there are three compounds that must be completely understood, namely: (1) reduction of data that continues throughout the project-oriented qualitative progress. Data reduction is part of the analysis process that emphasizes, shortens, focuses, removes unnecessary things, and arranges the data in such a 
way that the narrative of the data presentation and the conclusions of the problem units that have been studied in the research can be carried out. (2) Presentation of data is a narrative regarding various things that have happened or been found in the field, thus enabling the researcher to do something in the analysis or other actions based on his understanding. Data presentation other than in the form of sentence narratives can also include various types of matrices, pictures/schemes, activity-related networks, and tables to support the narrative. (3) Drawing conclusions, and verification. The conclusion needs to be verified so that it is sufficiently solid and can really be justified.

Next, namely ensuring the correctness of the findings found during the research process. The validity of this study used the triangulation method. According to Sugiyono (2013) triangulation is a study in which researchers use different data collection - different. One way of obtaining data is by conducting interviews at different times and with different informants. The type of triangulation used by researchers is source triangulation where source triangulation is an examination of sources that utilize different types of data sources to explore similar data.

\section{RESULTS AND DISCUSSION}

The following is a summary of the informant's statements made by the researcher through interviews with key informants and key informants who are briefly presented in the narrative.

Wulandari (Female, 26 years old) is an e-commerce owner of the Ils Project. The informant has been running an online sales business since 2014 and using the online to offline sales method since 2018. The informant said that the application of the online to offline sales method provides many benefits in running his business now. The increase in the number of consumers who buy the informants' products, of course, this also increases the profits obtained by the informants. The informant added many things that must be prepared when applying this sales method. In addition to preparing a stock of goods, shopkeepers must also be available in offline stores and admins who serve consumers online are also different when serving consumers in physical stores. Regarding the difficulties that were encountered during the informant's implementation of the online to offline sales method, the informant said that sometimes the production team was unable to meet stock production because all products were made through handmade, the manufacture went through a fairly long and long process.

In gaining consumer confidence, the informant said that online sales alone are very delicious because they do not require very much money. But consumers often do not believe in products offered online because there is no physical evidence. The informant added that with the online to offline sales method, consumers have more confidence in the products they offer because consumers can see first whether the goods they are going to buy are appropriate or not.

Junia Budi (male, 24 years) is an e-commerce owner of Nata Jaya Makmur. Informants have been using the online to offline sales method for more than one year. The informant said that the basis for using the online to offline sales 
method is because of the need to get more profit besides that also because of social status. The informant added that since the informant used the sales method, the informant's production of goods had increased along with the increasing number of consumers who bought goods from the informant. The informant also said several things that must be evaluated, namely the location of the offline store which must be strategic, making it easier for consumers to find their offline shop when consumers want to pick up the goods they have ordered.

Regarding consumer trust, the informant said that he tries to provide real information when offering his products online so that consumers have more confidence and are not afraid that the quality of the goods is not good when taking the goods at the informant's offline store, besides that informants provide the best possible service so that consumers feel satisfied. The informant also added that they must be ready and responsive when consumers need help and can provide solutions.

Deksya (male, 26 years old) is an e-commerce owner of Little Manggo. The informants have been using the online to offline sales method for almost a year. According to the informant, the online to offline sales method is very good to apply because this sales method can complement each other online and offline. Informants said consumers were satisfied while buying their products because consumers not only could see the products offered through social media but consumers could also come directly to the informant's physical shop. The informant added that while using the online to offline sales method, the sales increase of the informant's products was increasing.

Regarding consumer confidence, the informant also said that the presence of an offline store can also answer doubts from consumers regarding the products offered by the informants. In addition, informants can also expand the product market offered.

Meika Yanti (Female, 24 Years), an informant, has been buying things online for a long time. The informant said that he had felt disadvantaged when buying goods online because of the incompatibility of the items offered online with those obtained by the informants. The presence of physical evidence is very important to gain consumer trust.

Regarding the online to offline selling method, the informant said that he had transacted online and took the goods at the seller's physical shop. This method is very good to be applied because the informants can see in advance the items to be purchased. The informant also added that the services provided by $e$ commerce online are indeed a bit long when replying to a chat, but when in a physical store the seller provides very good service. The seller gives the advice to check the goods first, whether they are suitable.

Edi ( male, 26 years old), an informant said that he had experienced a case of fraud when buying online products. The item ordered by the informant did not come even though the informant had previously sent the money, this made the informant feel disappointed.

Regarding the online to offline sales method, Informant said that he once purchased goods online and took the goods at the seller's physical store. According to the informants, the sales method is very nice to use because the informant was more confident and not afraid to be cheated again. The informant added when the informant finds difficulty selecting items to be bought or feel free 
to purchase products online, the seller has advised the informant to come directly to the seller's physical store. There, the informant is helped to make his choices according to the wishes of the informants.

E-commerce requires a strategy to optimize its business. Strategies are steps that must be taken by the e-commerce industry to achieve a goal. The method of selling online to offline is a strategy that can be used by industry players of $e$ commerce, where this method is a merger between the sales online and offline. consumers transact online then take the goods that have been purchased by the consumer at the seller's physical shop. Rerung (2018, Page 20) said that the method online to offline is a type of e-commerce that attracts customers from channels online to a physical store. While many traditional retailers can be replaced by e-commerce, there are elements of offline shopping that cannot be done digitally. In addition, consumers can see the condition of the goods to be purchased before the consumers actually buy the goods.

The success of the strategy used can be seen from the development of the business being carried out. According to Henry (2007) said several indicators in determining business success, namely: (1) Profit. Profit is the main objective of running business. (2) Productivity and Efficiency. The size of the productivity of a business will determine the size of the production. This will affect the size of the sale and ultimately determine the number of opinions that will be obtained. (3) Competitiveness. Competitiveness is the ability or toughness to compete for consumer attention and loyalty. (4) Competence and Business Ethics. Competence is the accumulation of knowledge, research results, and experience quantitatively and qualitatively in their fields so that they can produce innovations in accordance with the demands of the times. (5) Build a Good Image. A good image of the company is divided into two trusts internal and trust externally. Internal trust is security or from all the people in the company. Meanwhile, external trust is the emergence of trust from consumers, suppliers, and competitors.

Assessing the development of the use of online to offline selling methods in the E-commerce industry in Denpasar can be seen from interviews conducted by researchers with each of the information regarding the use of online to offline selling methods in the e-commerce industry in Denpasar, namely: many benefits are obtained when e-commerce use the right methods online to offline, among others, increasing the production of goods e-commerce because of the availability of places to deviate or display the products of informants, until the consumer can see and choose - choose directly than viewing them through i social media. In addition, since using the online to offline sales method, the number of consumers who buy e-commerce products has increased so that it can increase the profits earned by e-commerce. Research conducted by Selvaraj, S. et al (2020) who said that the service online to offline is considered useful for freight management companies to improve customer service, reduce costs and overhead and increase profit margins. It can be said that the online to offline sales method has a very positive impact on providing benefits when used as a sales method.

The informant said that the choice of the offline store must also be strategic to make it easier for consumers to take goods that have been ordered online, besides that there are other benefits of using offline stores, apart from ordering products through the online to offline sales method, consumers can 
also come directly to the $e$-shop's offline store. commerce without making transactions via online first. At the online store, consumers also get real service. In addition, consumers can also see and choose other e-commerce products in addition to seeing products online. Offline stores also have an important role in the successful use of online to offline sales methods. According to Faizah, NK (2018) the advantage of offline services is that sellers and buyers can interact directly so that they can build a close relationship between the two. Consumers who use offline services will usually pay for groceries in cash. This direct payment makes transactions using offline services safer. In addition, customers do not need to worry about payment failures and fraud. Consumers get easy to trust because of real shops and products. Consumers can choose their own desired model, try the appropriate size, and find out the quality of the materials used. Direct experience with products is the reason why consumers have high trust in offline services. Chiang, I. P. et al (2018) adds that the main reason consumers choose to buy through physical channels is that they can provide quality services better sales and have the risk of spending is lower, however, if consumers care about price and promotion, they tend to lean towards the Cellular line.

In accordance with the research conducted by Yang et al (2016) who researched What Drives Online to Offline Commerce: From a Perspective of Consumer, where the results of their research found that many benefits were obtained by implementing online to offline. Online benefits that can be felt by consumers are easy ordering, access to product information, attractive price discounts, and so on. As for the offline advantage, consumers can check the goods themselves, feel the texture, or pick up goods in real stores. Both of these services have their own advantages, if the two concepts are applied together, of course, there will be many advantages for industry e-commerce.

Research conducted by Nuraini, D \& Evianah (2019) states that there are differences in consumer satisfaction when buying products online or offline. When consumers buy products online consumers cannot see the real product directly, because consumers can only see the product based on photos or images, and this can disappoint consumers if the product is not as expected, besides that consumers are also charged for the cost of sending the product. Meanwhile, offline shopping does not have additional shipping costs because the buyer comes directly. But to get to the seller's place you also need transportation. Likewise, the quality of products purchased via offline, physically you can immediately see and hold the text of the product, so basically buying online or offline has its advantages and disadvantages, but when used simultaneously, it will certainly be profitable if you see that each sales method has its advantages. each.

In this study, it was also found that the online to offline selling method can answer every doubt from consumers, where before buying an $e$ commerce product, consumers can first see whether the product they are going to buy is in accordance with the wishes of the consumer. Consumers are also not afraid to be a case of fraud that will befall the consumer when buying products online. In addition, having an offline store can change the social status of $e$ commerce. One of the informants said that while using the online to offline sales method and having a physical store, the informant was seen as an entrepreneur.

The rapid growth of e-commerce in Denpasar has made the potential 
for online to offline services to be of great interest to e-commerce businesses. This can be seen from the statements of the informants while applying the method. Service online to offline become an alternative for the industry of $e$ commerce because service online to offline has some advantages that address concerns of consumers, marketing accurate, the number of subscribers increasing and revenues that will be obtained will increase.

Compared to pure online trading, the online to offline service method has many benefits and allows customers to get complete product information when customers visit a physical e-commerce store so that it becomes an advantage in itself for online commerce. One of the important problems of online shopping is that consumers cannot try before ordering. Consumers also do not get real services and only get information about the goods they will order through browsing web pages or social media that are used by e-commerce as a medium to introduce their products. Sometimes online shopping can be a disappointing experience simply because the goods they order don't suit the consumer's wishes. One of the goals of this online to offline service method is to take advantage of both online trading and offline trading.

Soegoto, S. A (2013) states that trust that is built from scratch will foster a sense of consumer loyalty to the goods or services offered. Consumer trust is the consumer's expectation that a provider of goods or services can be relied on in fulfilling their promises. Running a business by using e-commerce, consumer confidence in the products that we offer is a part of things that are very important. When shopping online, buyers only rely on promises made by the seller. The buyer will not know whether the product is in accordance with the wishes of the buyer and the transaction is safe from cases of fraud or not.

Based on the researcher's interviews with the three key informants and the main informant who said that the presence of physical evidence is necessary to answer any consumer doubts when buying products online. Physical evidence is a form of actual physical actualization that can be seen or used by e-commerce in accordance with its use and utilization which can be felt to help the services received by people who want services, so they are satisfied with the services they feel (Parasuraman, 2001). In line with research conducted by Wartini, S and Setiono, G (2017), the results of their research say that there is a positive and significant effect of physical evidence on consumer loyalty. This means that the higher the physical evidence that supports a service, it will increase consumer loyalty. Consumer satisfaction obtained through physical evidence makes consumers more confident to buy the products offered $e$ commerce is repeated. Meanwhile, research conducted by Armanto, ID (2018) also states that physical evidence affects customer satisfaction at PT Telkom Indonesia Tbk Witel Denpasar. These results indicate that the higher the quality and level of physical evidence given by the company, then it will be the higher the level of customer satisfaction. It can be said that physical evidence has an important role in increasing consumer confidence because the absence of physical evidence makes consumers hesitate to buy the products offered.

Based on the researcher interview with the three key informants and the main informant who said that consumer trust can also be obtained through the services provided by e-commerce during the transaction process. This is supported 
by research conducted by Kosasih, MPP (2016), from the results of his research, the results show that depth has a significant influence on purchasing decisions and the seriousness of the company to provide good service in meeting customer needs will affect purchasing decisions. Reliability is the company's ability to provide services as promised accurately and reliably. Services provided must be following consumer expectations which means timeliness, the same service for all consumers without errors, a sympathetic attitude, and high accuracy (Tjiptono, 2012). When e-commerce provides fast and accurate service, it certainly makes consumers feel satisfied. Also, consumers will increasingly trust to buy or use the services offered by e-commerce. The essence of reliable service is that every $e$ commerce must have reliable and accurate capabilities so that it can serve consumers well. Of course, this will establish good communication between $e$ commerce and consumers.

Based on the researcher interview with the three key informants and the main informant who said that e-commerce preparedness in responding to every request from consumers is very important because it also has an impact on consumer trust. This is supported by research conducted by Kosasih, MPP (2016) from the results of his research that the results show that responsiveness has a positive and significant effect on purchasing decisions. The company's ability to provide services responsively and quickly to consumers will greatly influence consumer purchasing decisions. Responsiveness is the response or readiness of employees to help and provide services quickly and responsively. Responsiveness can foster a positive perception of the quality of the goods or services provided (Kotler and Keller in Sabran, B. 2012).

When e-commerce responses provide fast or responsive as well as accompanied by the means of delivering clear and easy to understand of course it has its own value to gain the trust of consumers. In addition, $e$ commerce readiness in assisting consumers in providing services and handling consumer complaints will make it easier for consumers to enjoy services or products so as to increase consumer confidence in enjoying these products and services.

Based on the researcher interview with the three key informants and the main informant who said that the guarantee of providing true product information will make consumers feel satisfied and happy to buy $e$ commerce products repeatedly. This is supported by research conducted by Armanto, ID (2018) from the results of his research, it is found that the guarantee has a positive effect on customer satisfaction at PT. Telkom Indonesia Tbk Witel Denpasar. The results of his research show that the higher the guarantee provided, the higher the level of customer satisfaction. According to Kotler and Keller in Sabran, B. (2012). The guarantee is the company's knowledge to build trust and confidence in consumers in buying the products or services offered. The guarantees provided by e-commerce are very important because they involve consumers' perceptions of the risk of uncertainty about the goods or services offered.

The form of certainty of service is very much determined by the guarantee of e-commerce that provides services so that consumers who receive the service are satisfied. Guarantee and certainty obtained from good $e$ commerce communication courtesy and knowledge, so as to foster consumer confidence. In addition, e-commerce is also expected to provide real product 
information.

Based on the researcher interview with the three key informants and the main informant who said that e-commerce must have a sense of empathy to consumers. A sense of empathy will make e-commerce e able to understand every problem experienced by consumers. According to Lupiyoadi (2016), empathy is giving sincere and individual or personal attention to customers by trying to understand consumer desires. Where a company is expected to have an understanding and knowledge of customers, understand specific customer needs, and have a comfortable operating time for customers.

In line with research conducted by Wartini, $S$ and Setianto, $G$ (2017) which proves that the higher empathy in the minds of consumers provided by employees to consumers can be in the form of greetings and ask the needs or desires of every consumer who comes and is willing to provide information that consumers need. it will also affect the increase in the level of consumer loyalty.

Giving sincere and personal attention to consumers, this is done to find out what consumers want accurately and specifically. In addition, giving sincere attention and answering any questions asked by consumers will make consumers feel at ease when buying the products offered. A sense of empathy is very important for e-commerce because it will help e-commerce understand the feelings of consumers so that $e$-commerce can provide an appropriate response.

Service online to offline a merger between the trade online and offline, where consumers transact online and then pick up the goods that have been purchased by the seller to ordinary consumers. Of course, with such a method will foster consumer confidence in online products because consumers do not feel afraid of quality or consumer mismatches with the goods to be purchased because consumers can see the goods or try the items purchased first. In line with the research conducted by Widjaja, A and Giovanni, Y (2018) entitled Impact of Online to Offline (O2O) Commerce Service Quality and Brand Image on Customer Satisfaction and Repeat Purchase Intention, the results show that online to offline services have a direct influence on customer satisfaction thereby fostering repeat purchase intentions. Repeated purchases made by consumers, of course, have won the trust of consumers by adopting online to offline services in the $e$ commerce industry.

The application of online to offline service methods is very influential in fostering consumer trust in online products. Application of service methods like this will make consumers not afraid to shop online because consumers can come directly to the physical store owned by e-commerce. Besides being able to see the goods that will be purchased by consumers, consumers can also assess the real services provided by e-commerce. E-commerce must be able to apply the dimensions of online to offline services in its physical stores. The dimensions of the quality of services online to offline (020) in the form of physical evidence ( tangibles ), Reliability ( reliability), responsiveness ( responsiveness), assurance (assurance), and empathy (empathy). If e-commerce can apply these dimensions, consumers will increasingly trust the products offered to consumers. Consumer trust will make consumers buy products that $e$-commerce offers repeatedly. The income earned by e-commerce will also increase. 


\section{CONCLUSION}

From the results of interviews conducted during the research process conducted by researchers entitled the use of the online to offline sales method in the e-commerce industry in Denpasar, it can be concluded that to answer the wrong formulation that the use of the online to offline sales method in the $e$ commerce industry in Denpasar and the method Online to offline sales can increase consumer confidence in e-commerce, namely as follows:

Many benefits are obtained when e-commerce using the sales method online to offline among others the increase in the production of goods and the growing number of consumers who buy e-commerce so that the increased profits earned by e-commerce. Besides other benefits of the use of an offline store, in addition to ordering the product via the method of selling online to offline, consumers can also come directly to the offline store owned e-commerce without making transactions via online beforehand. The selection of offline stores must also be strategic to make it easier for consumers to take goods that have been ordered via online, in this study it was also found that the online to offline selling method can answer every doubt from consumers and can change the social status of e-commerce.

The application of the online to offline sales method is very influential in fostering consumer trust in online products. This is supported by the 5 dimensions contained in the online to offline service. The results of research conducted by researchers through interviews with informants regarding the five dimensions obtained data, namely: the presence of physical evidence is necessary to answer any consumer doubts when buying products online. Consumers' trust can also be obtained through the services provided by e-commerce throughout the transaction process. The readiness of e-commerce in response to each demand of consumers is unbelievably important because it also has an impact on consumer confidence. Guarantees are secured to provide product information with truth will make consumers feel satisfied and happy to buy products $e$ commerce is repeated. E-commerce must have a sense of empathy for consumers. A sense of empathy will make e-commerce e able to understand every problem experienced by consumers.

The results of this study found a difference when compared to previous studies where research conducted by Zhang, J (2014) entitled Customer 'Loyalty Forming Mechanism of $\mathrm{O} 2 \mathrm{O}$ E-Commerce found that customer perceived value, customer satisfaction, customer trust, and customer transfer costs are the factors that affect customer loyalty to o2o e-commerce while in this study the researchers wanted to find first thing - whatever it can boost consumer confidence. In this study, it was found that the five dimensions of services online to offline in the form of evidence of physical, reliability, responsiveness, assurance, and empathy are things to improve consumers' trust. If consumer trust has been obtained by $e$ commerce, of course, this will make consumers loyal to buy products offered by $e$ commerce.

\section{REFERENCES}

Amban, HE 2016. Pengaruh Kualitas Layanan Online to Offline (O2O) Commerce Terhadap Citra Merek dan Perceived Value Serta Dampaknya pada 
Disonansi Kognitif dan Minat Beli Ulang Pelanggan. Master's Thesis in Management

Anggiani. S. 2018. Kewirausahaan: Pola Pikir, Pengetahuan dan Keterampilan. Second Edition. Jakarta: Prenadamedia Group

Armanto, ID 2018. Pengaruh Dimensi Kualitas Layanan Terhadap Kepuasan Pelanggan Indihome Triple Play. Jurnal Manajemen Udayana. Vol 7, No 3, 2018.ISSN: 2302-8912. Accessed from media.neliti.com

Bilondatu, MR 2013. Motivasi, Persepsi, dan Kepercayaan Pengaruhnya Terhadap Keputusan Pembelian Konsumen pada Sepeda Motor Yamaha di Minahas. Journal EMBA. Vol. 1, No.3. ISSN 2303-1174. Accessed from ejournal. Unsrat.ac.id

Chiang, IP. Lin, CY and Huang, CH 2018. Measuring the Effects of Online-toOffline Marketing. Journal Contemporary Management Research. Vol 14. No 3. Accessed from www.cmr-journal.org

$\mathrm{Du}, \mathrm{Y}$ and Tang, Y. 2014. Study on the Development of O2O E-Commerce Platform of China From the Perpective of Offline Service Quality. International Journal of Business and Social Science Vol.5 No. 4. Taken from www.ijbssnet.com

Faizah, N .K. 2018. Strategi Pemasaran Produk Pakaian dengan Sistem Online dan Offline di Toko Bibishop Grosir Nganjuk. Journal Ekonomi Manajemen. Retrieved from simki.unpkediri.ac.

Ferrinadewi, E. 2008. Merek dan Psikologi Konsumen. Jakarta: Graha Ilmu

Harahap, DA and Amanah, D. 2018. Perilaku Belanja Online Di Indonesia: Studi Kasus. Journal Riset Manajemen Sains Indonesia (JRMSI). Vol 9, No. 2, eISSN:

8313. Accessed from Https://Www.Researchgate.Net/Publication/3281248

61 Online_Shopping_Bhavior_Di_Indonesia_Studi_Case

Henry, $\overline{F N}$ 2007. Ekonomi Manajerial. Jakarta: PT Raja Grafindo Persada

Kosasih, MPP 2016. Keandalan, Daya Tanggap dan Empati Pengaruhnya Terhadap Keputusan Pembelian di Princess Cosmetic. Journal Manajemen dan Start-Up Bisnis. Vol. 1, No 2. Accessed from journal.uc.ac.id

Kotler, P. 2017. Marketing For Competitiveness . Yogyakarta: PT Bentang Pustaka

Lupiyoadi, R. 2001. Manajemen Pemasaran Jasa Teori dan Praktik. Jakarta: Salemba Empat.

Masruri, M and Creativity, J. 2012. Toko Online Canggih dengan WordPress. Jakarta: PT Elex Media Komputindo

Nuraini, D \& Evianah. 2019. Analisis Perbedaan Kepuasan Konsumen Terhadap Pembelian Produk Baju Secara Online Dan Offline. Jurnal Ekonomi Manajemen Akuntansi. Vol 15 No 2. Accessed from journal.uwks.ac.id

Parasuraman. 2001. Servqual: A Multiple - item Scale for Measuring Consumer Perception of Service Quality. Journal of Retailing. 64 (1): 12-37

Rerung, RR 2018. E-Commerce Menciptakan Daya Saing Melalui Teknologi Informasi. Yogyakarta: CV Budi Utama.

Sabran, B. 2012. Manajemen Pemasaran. Jakarta: Erlangga

Sakti, NWS 2014. Buku Pintar Pajak E-Commerce. Jakarta: Media Vision

Sarwono, J and Prihartono, KAH 2012. Perdagangan Online: Cara Bisnis di Internet. Jakarta: PT Gramedia. 
Satori, D and Komariah, A. 2017. Metode Penelitian Kualitatif. Bandung: Alfabeta

Selvaraj, S. Kim, H and Choi , E. 2020 . Offline-to-Online Service and Big Data Analysis for End-to-end Freight Management System. Journal of Information Processing System. Vol $16 \quad$ no. 2. Accessed from amazonaws.com

Setyawan. A, Sukadana. W and Saientisne, D. 2017. Peran E-Commerce Terhadap Penjualan Usaha pada Industri Pakaian Jadi di Provinsi Bali. Journal Ekonomi Pembangunan. Vol 6. No 12. ISSN: 2303-0178. Accessed from ojs.unud.ac.id

Soegoto, S. A. 2013. Persepsi Nilai dan Kepercayaan Terhadap Kepuasan dan Dampaknya Terhadap Loyalitas Konsumen. Jurnal. EMBA Vol. 1 No. 3. ISSN 2303-1174. Accessed from ejournal.unsrat.ac.id

Subagio, H and Veno, M. 2013. Analisa Pengaruh Kepercayaan Terhadap Tenaga Penjual (Trust in Employee), dan Kepercayaan Terhadap Merek (Trust In Brand) Terhadap Niat Beli (Purchase Intention) Konsumen pada Bernini Furniture di Surabaya dan Semarang. Journal Manajemen Pemasaran Petra. Vol. 1, No. 2 (1-2). Accessed from media.neliti.com

Sugara, A and Dewantara, RY 2017. Analisis Kepercayaan dan Kepuasan Terhadap Penggunaan Sistem Transaksi Jual Beli Online. Jurnal Administrasi Bisnis. Vol 52. No 1. Accessed from Media.neliti.com

Sugiyono. 2013. Metode Penelitian Pendidikan Pendekatan Kuantitatif, Kualitatif, dan $R \& D$. Bandung: Alfabeta

Suryani, T. 2013. Perilaku Konsumen di Era Internet Implikasinya pada Strategi Pemasaran. Yogyakarta : Penerbit Graha Ilmu

Tjiptono, F. 2012. Service Management Realizing Excellent Service. Yogyakarta: Andi

Wardhanie, AP, Kartika. P and Wulandari, SHE 2018. Pertumbuhan Bisnis Melalui Metode O2O pada Usaha Mikro, Kecil dan Menengah (UMKM) di Indonesia. Journal Ilmiah Bisnis dan Ekonomi Asia. Vol. 12, No.2. ISSN 2620-875X. ISSN 0126-1258. Accessed from https://www.jurnal.stie.asia.ac.id

Wartini, S and Setianto, G. 2017. Pengaruh Bukti Fisik dan Empati Tehadap Loyalitas Konsumen Melalui Kepuasan Pelanggan. Management Analysis Journal. Vol. 6 No. 4. ISSN 2252-6552. Accessed from journal.unnes.ac.id

Yang, Y. Gong, Y. Yu, B. Zhang, J. and He, T. 2016. What Drives Online to Offline Commerce: From a Perspective of Consumer. Journal of The Fifteenth Wuhan International Conference on E-Business - Mobile Technologies and Ubiquitous Service. Taken from pdfs.semanticscholar.org

Zhang, J. 2014. Customer Loyalty Forming Mechanism of O2O ECommerce. International Journal of Business and Social Science Vol. 5, No. 5 (1). Accessed from http://ijbssnet.com/journals/Vol_5_No_5_1_April_2014 / 19.pdf 